Fikrah: Jurnal Ilmu Aqidah dan Studi Keagamaan

issn 2354-6174 eissn 2476-9649

Tersedia online di: journal.iainkudus.ac.id/index.php/fikrah

Volume 8 Nomor 12020 , (1-24)

DOI: $10.21043 /$ fikrah.v8i1.6796

\title{
Strengthening Religious Provisions in the Era of Social Media for Children in the Ex-Localization Panjang Lampung
}

\author{
Fitri Yanti \\ UIN Raden Intan Lampung \\ fitriyanti@radenintan.ac.id \\ Eni Amaliah \\ UIN Raden Intan Lampung \\ eni.amaliah@radenintan.ac.id
}

\begin{abstract}
Abstrak
Artikel ini bertujuan untuk menggambarkan dan menjelaskan kegiatan bimbingan keagamaan era media sosial bagi anak-anak di eks-lokalisasi Panjang Bandar Lampung. Penulis menggunakan rancangan kualitatif untuk pengambilan sampel atau penentuan informan yang dilakukan secara langsung (purposif). Artikel ini mengungkap bahwa bimbingan keagamaan diperlukan dalam membentuk dan membina kehidupan keagamaan melalui media sosial karena intensitas interaksinya yang lebih dinamis dan semua pihak bisa menjadi subjek informasi dengan jaringannya yang terbuka untuk semua orang. Tingkat pengaruh media sosial saat ini terhadap kehidupan keagamaan penting untuk diketahui, Hasilnya adalah penguatan keaagamaan dan layanan keagamaan membuat dua implikasi kebijakan yaitu pengembangan wawasan integratif antara pendidikan formal dan nonformal serta penguatan wawasan penggunaan gawai atau smartphone sehingga fungsi antara pesan keagamaan yang disampaikan berjalan secara optimal.
\end{abstract}

Kata kunci : Bimbingan, keagamaan, lokalisasi, media sosial 


\begin{abstract}
This article aims to illustrate and explain the social media era religious guidance activities for children in the ex-localization of Bandar Lampung. The author uses a qualitative sampling design or the determination of informants is done directly (purposive).This article reveals that religious guidance is needed in shaping and fostering religious life through social media because the intensity of interaction is more dynamic and all parties can be subject to information with a network that is open to everyone. The current level of influence of social media on religious life is important to know. The result is the strengthening of religious and religious services making two policy implications, namely the development of integrative insights between formal and non-formal education and strengthening the insight of the use of devices, smartphones so that the function of religious messages delivered is running optimally.
\end{abstract}

Keywords: guidance, localization, religion, social media,

\title{
Introduction
}

Social media is an era where unlimited space and time is a vehicle for socializing with each other and done online that allows humans to interact with each other, both children, young and old, all ages have been loved by fast duration media (Sherlyanita \& Rakhmawati, 2016). We cannot close our eyes to technological advancements, which is unstoppable at the moment, but there must be brakes and limits in their use, the most important is the role of parents, family, environment and teachers (Sulthan \& Istiyanto, 2019). Parents as the first school children to shape the character of children by instilling religious values, values of goodness and others, By instilling these values children can have strong characters and can control themselves, giving examples of examples by teachers in schools can also be a reinforcement of his character, of course only parents and teachers must continue to monitor. However, it is inversely proportional to a coin in the ex-localization of Long Lampung with environmental and community conditions, the majority of which are prostitution service families.

The phenomenon of prostitution is a portrait of activities that involve many parties in a relationship, such as pimps, brokers, as well as consumers or customers who are commonly referred to as masher men. Prostitution is indeed rife in cities, cities bewitching their inhabitants to become "urban" towards foreigners. Modernity in the community creates a lifestyle that is currently the standard for the wider community (Moefad, 2015.) Specifically in Lampung Province precisely in the city of Bandar Lampung which is famous for the city of filter craft and is famous as a place of tourism, but there are also places of prostitution that are already well-known everywhere, one of the 
places that is the highlight of researchers is a place of localization of scenery, which is located in Kampung Rawa Laut Panjang Selatan, Panjang District, Bandar Lampung City, as one of the places that open services to have sex with prostitutes or dark cafes.

Rawa Laut is a village that is still a localization area, especially in the Bandar Lampung City area. Although the places that provide prostitution services are not as much as before the place was officially closed by the local government, but customers or guests still often arrive. now only a handful of places are still active in running the business of prostitution services or illegal cafes. Previously in 2002 the localization of the scene had been closed by the regional government of Bandar Lampung City based on the Bandar Lampung City Regulation No. 15 of 2002 concerning the prohibition of prostitution and prostitution in Bandar Lampung city area. But in reality the place is still being carried out by some local people even though in a tacit way. By looking at these phenomena about the rise of the prostitution environment that is still developing in Indonesia especially there is still that area in the Bandar Lampung City area which will certainly have a negative impact on the surrounding community especially for children as a generation of the Indonesian people going forward even the phenomenon of minors prostituting themselves has become a natural thing in the corner of Rawa Laut Village, Panjang Southern Village. Based on data from the Lampung Crisis Children Center (CCC) NGO. that children who become sex workers aged 15 years reached 25 percent, age 16 years with 32 percent and finally with the highest number of age 17 years as much as 36 percent (Antara, 2012).

Which is developed in the child is awakening of mind, words, and actions of children's which is done based on godly values or that comes from the religion they hold. Therefore it is expected that the child truly understands and practices the teachings in daily life. If someone has a good character related to God, then his whole life will be better because in the teachings of religion not only teaches to have good relations with God but also in others. Regrettably, the character that reflects a religious person does not always appear in everyone even though he has a religion. This happens because of a lack of awareness in its diversity. Even sadder if a person is religious confined to mere confession, but in practice daily life does not behave, have a view, and behave in accordance with the teachings of his religion.

Children are the future generation of the Indonesian nation, the next generation of the Indonesian nation, and the ideals of the Indonesian nation, 
so that the state is obliged to fulfill the rights of every child to survival, grow and develop. Therefore the state pays special attention to children by passing Law Number 35 Year 2014 which is Amendment to Law Number 23 Year 2002 concerning child protection. The law explains that children's rights are part of human rights must be guaranteed, protected, and fulfilled by parents, family, community, state, government, and regional government. Because after all the child has the right to obtain care, religious guidance and affection from his parents, but in reality it is sad to be obtained by children who live in an ex localization environment, because of the lack of role of family members in the care of children, and there are still many children who have incomplete parents, so there is a lack of harmonious relations between children and families.

The role of the environment in educating children is also no less important than the role of the family because a good environment will make the community in it good, and vice versa if the environment is bad it will also have a negative impact on the community in it. If there is a social environment in the social environment there will be a gradual influence on the community that lives around it, especially for children. Every day the children are always presented with scenes that are not appropriate to see by children who in the end the vision will cause stikma in children who fear they will follow the steps of what they see. Basically the child has inherited the character of imitating, what he sees and does what he knows he will apply in everyday life. Therefore, the inculcation of religious values needs to be taught to children from an early age because religious teachings are very important to guide human life because sufficient religious provisions will provide a strong foundation when it will act, in religious values containing the rules of life and self-control of actions that are not in accordance with religious law.

Religious education becomes important and a vein for the formation of religion from an early age, but in today's sophisticated era education is not only obtained from formal education but can also adjust the development of the era such as the era of social media that is rife at this age. In this modern era smartphone is not only as a communication tool but there are other advanced features, such as games, chat, facebook and others. And it can bring a variety of things to users. Like many people who get smarter by using sophisticated smartphones, therefore it should be a user especially for students to be smart in using smartphone. 
Referring to the above reality utilized above. To be able to take advantage of this era of social media, then children can be monitored in the use of smartphones, religious reinforcement becomes important When religion is confronted with so many channels Religious information is so easy to obtain, especially with search tools like Google which is very popular in Indonesian society. All information is only as far as the reach of the smartphone at hand. Everyone can get information from the website or blog. What level of influence of social media today on religious life is important to know. Is the intention to use social media in parallel with opium gadgets also have a tendency to religious emotions.

\section{Method}

This study uses a descriptive qualitative approach, because this study describes a certain object according to what it is in order to provide an explanation and answers to the subject being studied. As for the author population in this study consists of children from extended ex-localization in Lampung under the auspices of the Social Space Community (RUSOS) is a community engaged in social activities in the field of non-formal education of children formed with the aim as a forum for anyone who wants to come down directly to solve the problems that are around especially the problems of character and religious problems. Qualitative research prioritizes whole descriptive data from the phenomenon under study. Researchers also act as a tool or instrument for data collection. This research also not only stops until the description of a phenomenon, but will continue to involve the process of interpretation to interpret what is contained in it.

Data collection uses interviews, observation and documentation so that it can help the writer in gathering the required data. Data analysis is carried out on the data collected from the results of documentation, interviews and observations in the literature study to enhance research understanding of cases to be examined and presented to others as findings. Data analysis is carried out on the data that was collected from the results of documentation, interviews and observations in the literature study to increase the writer's understanding of the problem to be examined and presented to others as findings. Qualitative data, meaning that the data is then analyzed with interpretive descriptive techniques that are collected, compiled then interpreted and conclusions are drawn as necessary. Interpretation is done by interpreting the intentions of words or sentences from the data collected based on opinions and theories that have been there before. 


\section{Rawa Laut Village : Ex-Localization Panjang Lampung}

Rawa Laut Village : Ex-Localization at Panjang district is one of the sub-districts in Lampung, in this sub-district there is a container port, previously the port operating in Panjang was a port for passengers and finally now it has been changed by the Lampung Government to be just a container port. The Panjang port which is an export-import port for Lampung and also the Srengsem Port which is a port for coal distribution traffic from South Sumatera to Java. About 92 kilometers from the south of Bandar Lampung, there is Bakauheni, which is a port city in the Lampung province, precisely at the southern tip of Sumatera Island. Located at the tip of the Trans-Sumatera Highway, Bakauheni port connects Sumatera with Java via sea transportation. Harapan Panjang Beach is a prostitution place located in the Rawa Laut village of the southern Panjang in the Lampung sub-district, Panjang district, in this village there is a prostitution which is called the Harapan beach of Panjang village located on the edge of the ocean and also close to markets, terminals and the long police station.

Rawa Laut village which is located on the coastline of Bandar Lampung Town is a famous place of localization located in Rawa Laut Village at Panjang Subdistrict, Bandar Lampung City, which is an area better known as Harapan Beach, is an ex localization environment that has been officially closed for years. last year based on the Bandar Lampung City Regulation No. 15 of 2002 concerning the prohibition of prostitution and prostitution in the Bandar Lampung city area, but the activity of sex transactions continued to take place secretly.

Rawa Laut is a village that is still a localization area, especially in the Bandar Lampung City area. Although the places that provide prostitution services are not as much as before the place was officially closed by the local government, but customers or guests still often arrive. now only a handful of places are still active in running these prostitution services or dark cafes. The closure of the Harapan Panjang beach localization was further emphasized in 2012 on the prohibition of prostitution and prostitution in the Bandar Lampung city area but sex transaction activities are increasingly becoming even sex workers involving many children and adolescents who take place in secret. 


\section{The Life Practices of Rawa Laut Village}

For the community, especially women, they can not meet the economic needs that are now all too expensive. In addition to the pressing of their economic crush they are also demanded to meet the economic needs that they are currently facing. If viewed from the economic side of prostitute female workers they are those who have no further education and limited ability. The factors that are factors in the high level of unemployment are the weak level education, social and economy for the poor people, and also supported by the limited ability of human resources owned by the community itself. The impact of this problem is the high rate of prostitution.

Prostitutes who carry out their profession voluntarily and forcefully are based on certain motivations, such as carrying out prostitution because of being held captive or being framed and forced by promises of jobs, which consist of syndicates of illegal organizations with sweet persuasions and promises. Hundreds and even thousands of girls from the village was promised to get a job, but the world of prostitution was used as their job. In general there are 2 things that encourage a woman to do professions as a female prostitute including: 1 . environmental conditions which include: a). The susceptible tuna women from low economic families. b). Have suffered emotional injury). Early marriage at the age that resulted in many divorces. 2. Individual characteristics include: a). Low level of education. b). Being uncontrolled in interacting with the opposite sex c). Physical colloquity which is the only basic capital.d) High desire to be respected in society.

\section{The Behavior "mimic" Shapes the Character of the Child}

Children are the next generation of the nation, in their hands is the fate of a nation. If a child has a low religious and moral destiny, a nation will experience destruction and is full of crime. Conversely, if children have good religion and morals, the fate of the nation will be developed and peaceful. For that, children need to get a good education as early as possible so that children will grow and develop into human beings who have a strong personality. One education that is sought is religious and moral education. Moral religious education is very important for children. Because moral religious education is one aspect that must be developed in children.

The age of the child is the most important and basic early period in the entire range of growth and development of human life. One of the characteristics is the golden ages or the golden period. Where the 
development of intelligence at this time has increased to $50 \%$. In this period experiencing the maturation of physical and psychological functions that are ready to respond to the stimulation provided by the environment. This period is a time to put the first basis in developing physical abilities, cognitive, language, art, social emotional, self-discipline, religious values, self-concept and independence (Isjoni, 2011).

Suryadharma Ali stated, that providing education at a time when childhood is more pervasive and will be the basis in the next life, because the first thing that enters his soul will be the foundation for his abilities and expertise. The development of children in the next phase will be much influenced from this foundation (Suryadharma, 2013). In educating children that must be developed is a moral value, because with the provision of moral value education from an early age is expected at the next stage of development of children will be able to distinguish good and bad, right where they should do and that do not need to be done. So, he can apply it in daily life days that will affect whether or not children are accepted in the surrounding community in terms of socializing.

In children's educational institutions moral and religious values are instilled among others through the example of parents and the surrounding environment. Children tend to emulate what is often seen to imitate the same actions. Learning will be empathetic and more meaningful if the educator tries to present a real situation in the form of daily activities both at home and the daily environment. The learning process is instilled continuously and directly through the exemplary method. By doing so it is hoped that learning will have an influence on children's daily behavior.

According to Albert Bandura and Richard Walters, imitating someone's behavior is the result of interaction of factors in the self (cognitive). There is a process of the importance of imitation behavior theory: Attention Process is that before imitating another person, attention must be paid to that person. This concern is influenced by the observer's association with his model. The representation process is that the behavior to be imitated must be symbolized in memory. Both in verbal form and in the form of images. One part of the behavior is imitating behavior. People do not directly become models imitated by children. What is seen and learned from parents, what is felt and experienced by children, including things that are fun, painful, or proud will be felt in the inner child. Through interaction in the family, children not only identify (unite mix) themselves with the life of society and the natural surroundings. 
The role of parents is very important as meeting the child's needs for love, attention and security and other needs with the right dose. The absence of parents physically and emotionally can have a negative effect on children. To be able to create pious and pious children it is not enough to just give principles, because what is more important for children is the figure who exemplifies applying these principles. So that as much as any principle is given without being accompanied by example, it will only become a collection.

The need for moral development and religious values since childhood, starting with early childhood, for example, parents accustom their children to behave politely like kissing the hands of parents when shaking hands, saying goodbye when leaving and want to share toys, want to work together, not angry, want to forgive, then naturally such behavior will become their daily habits. The focus of learning is meaningful in accordance with the view that learning is constructing knowledge, in which students understand their experiences. Meaningful learning is seen as an important educational goal which requires learning not merely to convey factual knowledge and also requires assessment questions that require students not to merely remember or recognize factual knowledge

The rapid development of social media makes many changes for the community, especially children whose intention to use social media is parallel with opium gadgets. Because with social media, the real world life can be transformed into "the virtual world" (Soliha, 2015). Coupled with a less environment good so that the impact of social media easily influences the behavior of children that exceeds normal limits. technological advances are not unstoppable at this time, but there must be brakes and limits in their use, the most important is the role of parents and the environment.

\section{Unlimited use of Social Media}

Social media is a vehicle for socializing with each other and done online that allows humans to interact with each other without being limited by space and time (Ningrum, 2017). We cannot close our eyes to technological advances that are not unstoppable at this time, but there must be brakes and limits in their use, Social Media (Social Networking) is an online media where its users can easily participate, share, and create content including blogs, social networks or social networks, wikis, forums and virtual worlds. Blogs, social networks and wikis are perhaps the most common forms of social media used by people around the world. Andreas Kaplan and Michael Haenlein define 
social media as "an internet-based application group that builds on the ideology and technology of Web 2.0, and that enables the creation and exchange of user-generated content" (Putri, Nurwati, \& S., 2016).

Social media is an online media for socializing with each other without limited space and time. The popularity of social media is supported by the ease of teenagers in receiving and sharing information through these media. The time required is not long, only with a few seconds, teenagers easily obtain all the information needed. Social media makes it easy for users to share ideas, suggestions, views, activities, information, events, invitations and interests in each person's individual network (Kemendag, 2014).

Basically, social media is a place for information communication, just like newspapers, television, radio, and so on. The difference is in the intensity of the interaction that is more dynamic and all parties can be the subject of information with a network that is open to everyone. All can be involved and can produce information, but this will sacrifice control over the information created and disseminated (Cahyono, 2016). All can be involved and can produce information, but this will instead sacrifice control over the information created and disseminated.

Children's development towards maturity is influenced by the outside world, that is, by cultural changes that make social expectations possible at each stage. The more advanced a civilization, the change in culture and social expectations are also more advanced. One characteristic of the advancement of a civilization as is happening in modern times like today is the more electronic media used. So that electronic media can support or even hinder the development of its users. Some researchers found that exposure to social media influences individual development, seen in the results of children's developmental achievements affecting aspects of development such as physical, social, emotional, linguistic, cognitive, and moral.

Nowadays social media has become a necessity for almost all elements of society, not only in cities, villages, children, teenagers and parents, because of its ease of access to it, namely with mobile phones, who does not currently have a mobile phone. Social media has become an addiction that makes users no day without opening social media. The use of new media has a significant effect on patterns of social interaction in children aged 8-12 years. When children with high levels of media use, social interaction are indirect or mediaed, sociability tends to be low, social sensitivity tends to be low, tends to be aggressive, prioritizes content over relationships in communication, and tends to be egalitarian (Efendi, Astuti, \& Rahayu, 2017). 
Elementary school-age children are also very fast in learning the use of technology devices that are widely used by adults such as mobile phones and laptops that are connected to the internet so as to provide extraordinary access to a wide variety of sites and many applications that are provided free of charge. Many types of mobile phone brands today provide social media features that are free and very easy to download, such as Facebook, Twitter and Instagram, which at present are the most widely used social media applications among our people (Fitri, 2017). along with the development of existing technological devices and their applications and here we will examine what else is a positive or negative impact of social media, especially in changing children's social life in their schools and at home. All can be involved and can produce information, but this actually compromises control over the information created and disseminated.

\section{Strengthening the provision of "insightful" religion}

Revealed that the values developed in cultural education and national character came from the following sources, namely religion, Pancasila, culture, and national education goals (Kemendiknas, 2010). Religion became a source of character education because Indonesia is a religious country so the values contained in religion is used as the basis for shaping character (Ananda, 2017). The points of values developed in cultural education and national character are grouped into five main values, namely character values in relation to God, self, others, the environment, and nationality. The character value that has to do with God is a religious value.

Rawa Laut village at Panjang village office of Panjang District, Bandar Lampung City, which is an area better known as Harapan Beach, which still exploits children to become sex workers. Therefore, what can be done is a persuasive approach considering this location is still the location of prostitution by children to changing attitudes and behavioral beliefs by influencing the psychological aspects of children by requiring guidance, especially character development through a non-formal education process so that children become human beings who are of good character, knowledgeable, and independent, so that children's daily behavior is in accordance with the norms religion. Religious value is one of the controlling factors of behavior by children because religious values always color in human life every day. Block and Stark in divides religious aspects into five dimensions as follows (Arifah, 2009). 
First, Religious belief (aspects of belief), namely the existence of belief in God and everything related to the supernatural world and accepting dogmatic things in the teachings of his religion. This faith is the most basic dimension for followers of religion. Second, Religious practice (aspects of worship), namely aspects related to the level of agreement which includes the frequency and intensity of a number of behaviors, where the behavior has been fixed by religion such as the procedures for performing worship and religious rules. Third, Religious felling (aspects of appreciation), which is a description of the form of feelings that are felt in religion or how far a person can live the experience in religious rituals he does, for example, solemnness when praying. Fourth, Religious knowledge (aspects of knowledge), namely aspects that relate to one's understanding and knowledge of the teachings of his religion to add knowledge about his religion. Fifth, Religious effect (the aspect of practice), namely the application of what he has learned from the teachings of the religion he embraces then is applied through attitudes and behavior in daily life. Sixth, Religious effect (the aspect of practice), namely the application of what he has learned from the teachings of the religion he embraces then is applied through attitudes and behavior in daily life.

Furthermore, the Ministry of Environment explains five religious aspects in Islam are (Thontowi, 2005) first, Aspects of faith, which concerns human beliefs and relations with God, angels, prophets and so on. Second, Islamic aspects, namely regarding the frequency and intensity of the implementation of worship that has been determined, for example prayer, fasting and alms. Third, Ihsan aspect, which involves the experience and feelings about the presence of Allah SWT by carrying out His commands and avoiding His prohibitions. Fourth, the aspect of science, namely concerning one's knowledge of religious teachings, for example by exploring the Koran further. Fifth, Charity aspects, concerning behavior in social life, for example helping others, defending the weak, working and so on.

The dimensions and aspects of the religious values above become a reference for instilling religious values in children through character education. The existence of descriptions and indicators of religious values will make it easier to arrange activities that will be arranged in the implementation of religious values in the home and surrounding environment. As the caliph of Allah who is believed to govern the world and everything in it, children from birth have brought the potential to be educated, in religious language it is said to be fitrah, about fitrah, Allah Almighty says which means: 
"Then face your face outright to religion (Allah); (Stay on) the nature of God who has created humans according to that nature. There is no change in the nature of God. (That is) right religion; but most humans do not know" (QS Al-Rum (30): 30) (Quran, 2001).

Some solutions to fortify students in using social media are First, Providing Islamic education in schools systematically, seriously and thoroughly, because religious education is a solid foundation for every human being. Through religious education, humans can strive themselves to always do good things. Secondly, in providing learning to students, educators should have good competence and capacity in accessing information and communication technologies such as social media so that educators are able to provide monitoring, guidance and teaching as an effort to give students a comprehensive understanding of all matters relating to information and communication technology so that it can lead to the use of a positive impact on students' religious behavior. Thirdly build communication and cooperation with parents so as to create a harmonious division of supervision and monitoring tasks between parents and school so that the interaction between students and social media can be monitored, controlled and controlled so that its use is driven towards the use of positive social media in the formation of students' religious behavior (Abidin, 2019).

Religious education includes two dimensions of life, namely the cultivation of a sense of piety to God and the development of a sense of humanity to others. Planting a sense of piety to God as a dimension of life begins with the implementation of formal religious obligations in the form of worship, while the implementation must be accompanied by a profound appreciation of the meaningfulness of these worship services, so that the worship is not done solely as a ritual sheer, but with a deep conviction of its educational functions for humans.

Religion is very important for the guidance of human life because with enough religious provisions will provide a strong foundation when it will act, in religious values containing the rules of life and self-control of actions that are not in accordance with religious law. A strong religious value is the basis for students to become people who can control themselves from negative things especially when the social media is so circular in human life, especially for children. Strengthening religious provisions for social media users for children in localization. 


\section{Development of Integrative Insight}

Integrative approach is an approach in the form of combining one method with another method. Integration is done by emphasizing the principle of interrelation between one element with another element, so that it is hoped that an increase in understanding is more meaningful and an increase in insight because one learning involves more than one perspective.

The development of integrative insights between formal and nonformal education is a side by side. The approach to develop the ability of reason in the formation of knowledge based on interactions with the environment and experience in life. Accordingly, integrated learning approaches help children to learn to connect what they have learned with what they have just learned. Through learning theory means that learning takes place in the human organism through a meaningful process of relating new events or items to already existing cognitive concepts or propositions. This theory shows that learning for children will be meaningful if what they learn is related to what they know and experience.

In formal education with the existence of school policies that support and facilitate religious activities that can increase the faith and piety of students. Religious activities that are considered to be able to support the creation of a conducive situation are the existence of a policy for congregational prayers for school residents, Friday prayers at school, reading verses of the Qur'an guided by their respective class teachers, the availability of other facilities such as Islamic reading, Islamic tapes, Islamic images, etc.

The basic values in Islam are called the basic values of ubudiyah, morality/morality, and basic values of nizhamiyah/discipline. The basic values of ubudiyah include human activity as a servant of Allah and as his Khafilah on earth, the nature of serving or serving God at the same time to get his pleasure (QS. Az-Zari-yat: 56), which means: "And I did not create jinn and men but to worship me". The four pillars in the basic humanist religious values are: (1) learning to know (learning to know), (2) learning to do (learn-ing to do), (3) learning to be yourself (learning to be), and (4) learning to live together (learning to live together). All that becomes the core of Islamic humanism.

Based on the results of a survey of religious activities developed in order to improve the faith and piety of children in the ex-localization area of Harapan Beach, Panjang Selatan is the study and study of Islam (50\%), learning to read the Qur'an (20.83\%), religious discussion forums (12.5\%), 
Islamic studies (8.33\%), other activities (8.33\%) given religious awareness. have a glimmer of hope to improve themselves, local residents began to openly accept guidance and religious approaches especially in fostering children's character. Kampung Rawa Laut, Panjang Selatan, the multipurpose building began to function as a place of recitation in the afternoon.

In this media era, religious activities in schools give teachers the knowledge that social media cannot access good things, including about religion, and they are taught educating education that can be obtained from social media including religious messages lightly through games that can be accessed through mobile phones by using the internet so they can fill their time with positive things that they can through the cellphones they have. And besides that the school provides activities outside the lessons. Based on interviews with teachers shows that the development of extracurricular activities consists of several daily activities, weekly, daily activities consisting of: 1) Morning classes which are carried out every day with a schedule of three classes a day, guided by PAI teachers. 2) Dhuhr prayer in congregation. 3) Pray before starting the lesson and the end of the lesson led by the class leader. 4) Guidance for the circumcision of duha prayer is done by the PAI teacher. 5) Opening the lesson by reading the Qur'an based on verses that are relevant to the initial (thematic) lesson.

Indicators of success in creating conducive conditions include: 1) The creation of a harmonious, democratic, and communicative atmosphere in the school environment based on the values of faith and piety. Achieving this atmosphere requires a pattern of mutual respect both in the classroom and outside the classroom. The teacher must develop a partnership pattern with students, so students can communicate naturally. Students must get out of the atmosphere of "school prisoners" through the creation of a conducive situation. 2) The creation of "rules of the game" governing social and communication ethics that must be implemented by all school components. The rules made not only apply to students, but teachers must also carry out these activities. These school regulations are binding on anyone and violations of the rules will get sanctions in accordance with these regulations. 3) Availability of facilities that support the atmosphere of the creation of values of faith and piety. Students must be able to access various sources of information that can enhance their faith and piety that they can access from their smart phones or telephones. 
For non-formal activities with extracurricular activities must be directed at increasing faith and piety. This does not mean that extracurricular activities should include religious activities only by ignoring other activities. Other activities that are beneficial to the development of students' interests and talents must also be developed and the development of faith and piety must be included (inhern) in them. It may be that the extracurricular form is not a religious activity, but the values it contains can increase students' faith and piety. The desired information can also be profound and shared about religious material from social media such as Facebook, WA, Instagram and so on.

"Non-School Education is any organized and systematic activity outside the established schooling system, carried out independently or is an important part of broader activities that are intentionally carried out to serve certain students in achieving their learning goals" (H.D. Sudjana, 2001). The school also cooperates in overcoming various social problems experienced by students. Success indicators include: 1) Having a permanent pattern of cooperation between the school and parents of students in fostering students' faith and piety. 2) Having network access with various social and religious institutions in order to foster students' faith and piety in schools and in the community.

\section{Strengthening Insight into The use of Devices, Smartphones}

Basically, social media is a means of information related to the development of updated technology, where people can publish what we want online. For children and adolescents, cyberspace communication through social media is considered as an ideal place to experiment and explore identity search. Due to the ease in exploring the world of social media, adolescents access social media continuously and often cause the phenomenon of overuse or addiction.(Felita, Siahaja, Wijaya, Melisa, \& Chandra, 2016.) There are currently many elementary school students (SD) with aged between 6-12 years who are already proficient in operating and having various forms of new media.

Gadgets are like the needs of urban communities, and even become something that is normal for everyone without age limit. Devices in the form of smartphones (tablets), tablets and notebooks are familiar to today's children. Children tend to imitate what they see. So parents should also be able to limit themselves in using the device. Do not be too busy with the device 
when gathering together. Provide a day where the family spends time together without using a device, such as watching television together, doing outdoor activities, exercising, watching art shows and so on. This can teach children that there are many other activities that can be done besides playing gadgets.

One is proven if the development of children in excessive use will reduce socializing with friends and have a negative effect on education or the ability of EQ if daily activities are only on social media. The generation of children now spends their time on social media without socializing around them directly in the real world. Children who are available as a medium of play are important needs for him, in this information age can be called a computer or laptop into a media that is close to the world of children's play (Anisyah, 2018).

Many things we do not know about the development of children in influencing social media. Associated with positive and negative effects to be contradictory, that the impact of the internet depends on the use of social media. Early childhood must be effective direct communication so as not to depend on social media communication (Ningrum, 2017). Guidance of parents who can use it well and minimize the negative side of children in social media users to improve learning experiences and produce positive impacts.

Positively, technology such as social media can be an innovation in the development of learning in basic education in Indonesia. The alternative which is commonly referred to as Basic Technology Education (PTD) is one of the technologies in introducing technology early to Indonesian children, in the program students are allowed to be actively involved in interacting with technology so as to stimulate the development of problem solving skills, creativity, and innovation in the field technology, thus the technology education provided proportionally develops technology thinking skills and vocational skills as an accumulation of technological thinking processes (Felita et al., 2009).

Improved learning methods that are commonly obtained from social media that have mushroomed such as the presence of extraordinary and so broad impacts usually give a new color or face in the world education system, which is known by various terms of e-learning, distance learning, online learning, web based learning, computer-based learning, and virtual classes and virtual room propaganda, where all the terminology refers to the same understanding of information technology-based education. Religious 
information is so easy to obtain, especially with search tools like Google that are very popular in Indonesian society. All information is only as far as the reach smartphone in hand. Everyone can get information from web pages or blogs. The most common way is to follow a preacher's social media account and then religious material can be accessed at any time.

By providing training and understanding in the use of social media devices or smartphones children can get enlightenment as early as possible from religious accounts from preachers or religious groups on social media. The abundance of religious-themed messages on social media shows that it is easy to satisfy the desires of religious experience and knowledge. Not only preaching messages from favorite preachers, the phenomenon of visual messages (memes) in the form of photos or pictures with wisdom words or scripture verses also makes studying religion more enjoyable.

\section{Conclusion}

Nowadays social media has become a necessity for almost all elements of society not only in cities, villages, children, adolescents and parents, because of its convenience also to access it, namely with mobile phones, who now does not have a mobile phone is almost non-existent. Mobile has become almost the same needs as the primary needs. But on the positive side the flow of religious messages conveyed through social media, can affect religious attitudes there is a significant relationship between religious provisions, social activities, theological religious messages, liturgical religious messages, ethical religious messages, religious attitudes, and the condition of homes and families towards media behavior social. Special innovative program designed to save, protect, nurture and foster children of sex workers in the lokalisasi Panjang into other normal children with a pattern that includes aspects that need to be empowered in the context of fostering children's values and morals even more focused on integration material science and technology, strengthening religious provisions for users of social media, First, the development of integrative insights between formal and non-formal education. Second is the strengthening of insight into the use of devices, smartphones are used by those smart users, so that the function of religious messages delivered is optimal.

\section{References}

Abidin, Jaenal. (2019). Media Sosial dalam Mempengaruhi perilaku Keberagamaan Siswa dan solusinya melalui Pendidikan Agama Islam. Jurnal Wahana Karay Ilmiah, 3 (1).

Ananda, Rizki. (2017). Implementasi Nilai-Nilai Moral dan Agama Pada Anak Usia 
Dini. Jurnal Obsesi : Journal of Early Childhood Education 1 (1), 21 https://doi.org/10.31004/obsesi.v1i1.22.

Anisyah, Nur. (2018). Pengaruh Media Sosial pada Tumbuh Kembang Anak Usia Dini. Al Hikmah Proceedings on Islamic Early Childhood Education. 1(hal. 10).

ANTARA News Lampung, 1 September 2012.

Chandra, D.T. and Rustaman, N.(2009), .Perkembangan Pendidikan Teknologi Sebagai Suatu Inovasi Pembelajaran Pada Pendidikan Dasar di Indonesia. Jurnal Pengajaran MIPA,.14 (1).

Cahyono, Anang Sugeng.(2016). Pengaruh Media Sosial terhadap Perubahan Sosial Masyarakat di Indonesia. Jurnal ilmu sosial dan ilmu politik diterbitkan oleh Fakultas Ilmu Sosial dan Politik, Universitas Tulungagung. 9 (1), 152.

Efendi, Agus, Puwani Indri Astuti, and Nuryani Tri Rahayu.(2017). Analisis Pengaruh Penggunaan Media Baru terhadap Pola Interaksi Sosial Anak di Kabupaten Sukoharjo. Jurnal Penelitian Humaniora. 18, (2), 13. https://doi.org/10.23917/humaniora.v18i2.5188.

Felita, Pamela, Christine Siahaja, Vania Wijaya, Gracia Melisa, and Marcella Chandra.(2016). Pemakaian Media Sosial dan Self Concept pada Remaja, Jurnal Ilmiah Psikologi MANASA. 5 (1).

Fitri, Sulidar. (2017). Dampak Positif dan Negatif Sosial Anak. NATURALISTIC : Jurnal Kajian Penelitian Pendidikan dan Pembelajaran 1,(2). 119, https://doi.org/10.35568/naturalistic.v1i2.5.

Isjoni. 2011. Model Pembelajaran Anak Usia Dini. Bandung: Alfabeta.(hal.19)

Kemendiknas. (2010). Peraturan Pemerintah Republik Indonesia Nomor 17 Tahun 2010 tentang Pengelolaan dan Penyelenggaraan Pendidikan. Jakarta: Kementerian Pendidikan Nasional.

Lies, Arifah, (2009), Implementasi Pendidikan IMTAQ di SMP Negeri 2 Bantul, tesis: UNY.

Moefad, Agoes Moh. (2015). "Komunikasi Masyarakat Eks Lokalisasi Pasca Penutupan Dolly, Jurnal Komunikasi Islam. 5. (1).

Ningrum, Wahyu Relisa. (2017).Peran Orangtua dalam Menyikapi dampak Sosial terhadap Perkembangan Kepribadian Remaja awal. Call For Paper di Universitas Aisyiyah Yogyakarta .

Pusat Humas Kementerian Perdagangan RI. (2014). Panduan Optimalisasi: Media Sosial Untuk Kementrian Perdagangan RI. Kementerian Perdagangan Republik Indonesia Ministry Of Trade.

Putri, Wilga Secsio Ratsja, Nunung Nurwati, and Meilanny Budiarti S. (2016). Pengaruh Media Sosial terhadap Perilaku Remaja. Prosiding Penelitian dan Pengabdian kepada Masyarakat 3,(1) https://doi.org/10.24198/jppm.v3i1.13625.

Sudjana, S HD. (2001). Pendidikan Nonformal, Wawasan, Sejarah Perkembangan, Falsafah, Teori Pendukung, Azas. Bandung: Falah Production.

Suryadharma Ali. 2013. Mengenal Tradisi, Meraih Prestasi Inovasi Dan Aksi 
Pendidikan Islam. Malang: UIN-Maliki Press.

Sherlyanita, Astrid Kurnia, and Nur Aini Rakhmawati. (2016), Pengaruh dan Pola Aktivitas Penggunaan Internet serta Media Sosial pada Siswa SMPN 52 Surabaya. Journal of Information Systems Engineering and Business Intelligence 2,(1), 18 https://doi.org/10.20473/jisebi.2.1.

Soliha, Silvia Fardila. (2015). Tingkat Ketergantungan Pengguna Media Sosial dan Kecemasan Sosial. Jurnal Interaksi. 4. (1).

Sulthan,Muhammad, and S Bekti Istiyanto. (2019). Model Literasi Media Sosial bagi Mahasiswa. Jurnal ASPIKOM. 6. (3). 1077. https://doi.org/10.24329/aspikom.v3i6.

Thontowi, Ahmad (2005), hakekat Religiusitas. diakses dari.

http://Sumsel.kemenag,go,id/file/dokumen/hakikatreligiusitas.pdf.pada tanggal 2 januari 2014. 